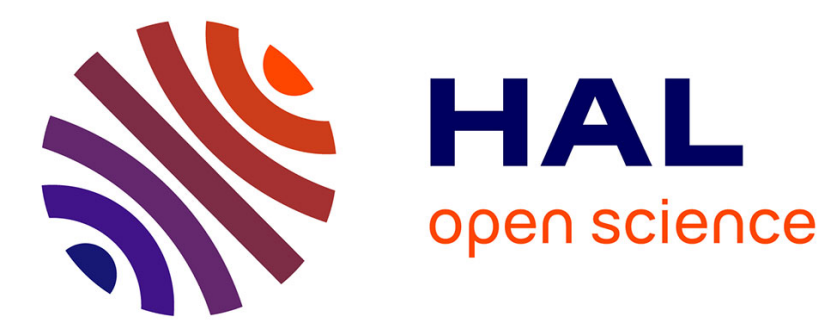

\title{
Progress in preparation and applications of Te-As-Se chalcogenide glasses and fibers
}

Zhihao Wu, Yinsheng Xu, Dongfeng Qi, Qiuhua Nie, Xianghua Zhang

\section{To cite this version:}

Zhihao Wu, Yinsheng Xu, Dongfeng Qi, Qiuhua Nie, Xianghua Zhang. Progress in preparation and applications of Te-As-Se chalcogenide glasses and fibers. Infrared Physics and Technology, 2019, 102, pp.102981. 10.1016/j.infrared.2019.102981 . hal-02279454

\section{HAL Id: hal-02279454 \\ https://hal-univ-rennes1.archives-ouvertes.fr/hal-02279454}

Submitted on 16 Dec 2019

HAL is a multi-disciplinary open access archive for the deposit and dissemination of scientific research documents, whether they are published or not. The documents may come from teaching and research institutions in France or abroad, or from public or private research centers.
L'archive ouverte pluridisciplinaire HAL, est destinée au dépôt et à la diffusion de documents scientifiques de niveau recherche, publiés ou non, émanant des établissements d'enseignement et de recherche français ou étrangers, des laboratoires publics ou privés. 


\title{
Progress in preparation and applications of Te-As-Se chalcogenide glasses and fibers
}

\author{
Zhihao $\mathrm{Wu}^{1,2}$, Yinsheng $\mathrm{Xu}^{1,3, *}$, Dongfeng $\mathrm{Qi}^{1,2}$, Qiuhua Nie ${ }^{1,2}$, Xianghua Zhang ${ }^{3,4}$ \\ ${ }^{1}$ Laboratory of Infrared Materials and Devices, Research Institute of Advanced Technologies, Ningbo \\ University, Ningbo, Zhejiang 315211, China \\ ${ }^{2}$ Zhejiang Provincial Key Laboratory of Photoelectric Materials and Devices, Ningbo, Zhejiang \\ 315211, China \\ ${ }^{3}$ State Key Laboratory of Silicate Materials for Architectures, Wuhan University of Technology, \\ Wuhan 430074, China \\ ${ }^{4}$ Laboratory of Glass and Ceramics, UMR CNRS 6226, University of Rennes I, 35042 Rennes Cedex, \\ France
}

\begin{abstract}
Te-As-Se (TAS) chalcogenide (ChG) glasses are suitable candidates for mid-infrared (MIR) applications. In this work, the formation, preparation of highpurity glasses and optical fibers, and the applications of TAS fibers were systematically reviewed. In this review, the thermal, optical properties as well as the fiber performance parameters of TAS glasses were summarized. Finally, the progress of TAS fibers in MIR applications, especially for sensor applications such as food monitoring and medical diagnostic were described in detail.
\end{abstract}

Key words: TAS glasses, MIR applications, FEWS, Fiber sensing 


\section{Introduction}

Chalcogenide $(\mathrm{ChG})$ glasses are composed IVA group elements ( $\mathrm{S}, \mathrm{Se}, \mathrm{Te})$, and added with heavy elements such as Ge, As and Sb, as shown in Fig. 1(a). Compared with traditional silicate glass, $\mathrm{ChG}$ glasses have many prominent features including ultra-wide infrared transmission range (up to $25 \mu \mathrm{m}$, Fig. 1(b)), lower phonon energy $\left(<350 \mathrm{~cm}^{-1}\right)$, higher linear refractive index $n_{0}(2.0-3.5)$ and nonlinear refractive index (100 to 1000 times higher than those of silicate glasses), ultra-fast optical response time $(<100 \mathrm{fs})$, excellent resistance to corrosion in atmospheric environment and tunable composition for different applications $[1,2]$. With the above superior performance, ChG glasses have been applied to infrared lens for night vision, phase change memories, electrolytes for batteries, waveguide devices for all-optical signal processing, photoresists for lithography and some new optoelectronic devices[3, 4].

\section{(a)}

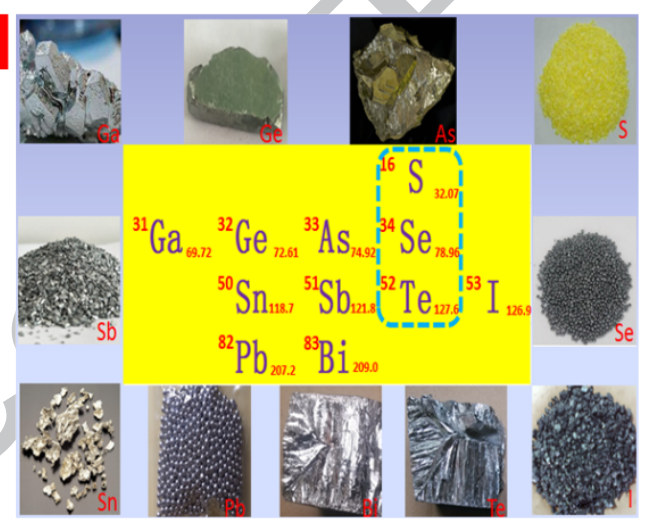

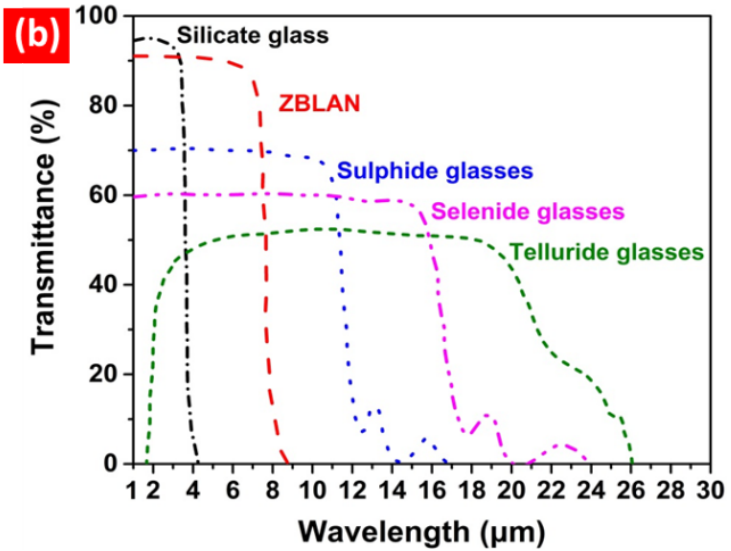

Fig. 1. (a) The commonly used elements for forming chalcogenide glasses and (b) transmission spectra of several glasses.

Besides, $\mathrm{ChG}$ glasses are suitable for drawing fibers. ChG fibers have low intrinsic losses, favorable bendability, stable chemical properties, high nonlinear coefficients and ultra-wide infrared transmission range (up to $\sim 26 \mu \mathrm{m}$ ). The ChG fibers have 
significant applications in the laser delivery [5, 6], transmission of thermal image[7-9], MIR supercontinuum (SC) generation[10-12] and infrared sensing[13-15] since covering the molecular fingerprint region of 3-13 $\mu \mathrm{m}$ MIR bands. To be drawn to a fiber, the glass is required to possess the good thermal stability. Usually, the difference of $T_{\mathrm{x}}$ and $T_{\mathrm{g}}$ larger than $120{ }^{\circ} \mathrm{C}$ is the minimum value to avoid crystallization during the drawing process. Until now, ChG fibers such as As-S, As$\mathrm{Se}, \mathrm{Ge}-\mathrm{As}-\mathrm{Se}$, Ge-Ga-Sb-S (Se), etc are successfully fabricated. Among numerous ChG glasses, TAS glasses have been widely investigated since their excellent thermal stability for drawing fibers and broad transmittance in the MIR[16-18]. TAS fibers have low transmission losses in the $2-18 \mu \mathrm{m}$ bands, especially in the range of 2-12 $\mu \mathrm{m}$, which is an ideal medium for detecting fingerprint region molecules $[19,20]$. Moreover, TAS fibers have excellent resistance to water, corrosion and electromagnetic interference. They could not only monitor and identify in-situ and long-distance real-time substances in harsh environments such as high temperature (around $100^{\circ} \mathrm{C}$ ), electromagnetic interference and toxic, but also realize the detection of special aqueous solutions, biological tissues[21], liquids and gaseous substances with infrared characteristic absorption spectra, which has been attracted extensive attention in the fields of biochemistry, microbiology, medical diagnosis, etc[22].

Although TAS glasses have been investigated for half a century, there is no detailed review that summarizes the glass forming, fiber drawing, and applications until now. In this review, we retrospected the formation of TAS glasses first, followed by summary of glass purification technique, the thermal and optical properties of TAS 
glasses. Finally we introduced the research progress of TAS glasses and fibers in MIR applications and made a prospect.

\section{Formation of TAS glasses}

\subsection{Formation and properties of TAS glasses}

In 1976, Kotkata et al. first reported the TAS glasses[23]. Generally, ChG glasses were prepared by melt-quenching technique in the vacuumed ampoule ChG glasses [24-26]. As shown in Fig. 2, TAS glass formation domain was relatively large, including As-Se, As-Te, Se-Te binary systems [27, 28]. The As-Se binary system had better glass forming ability than that of As-Te and Se-Te. In the TAS ternary system, the glass forming domain was located in the Se-rich region, which was biased toward the As-Se side.

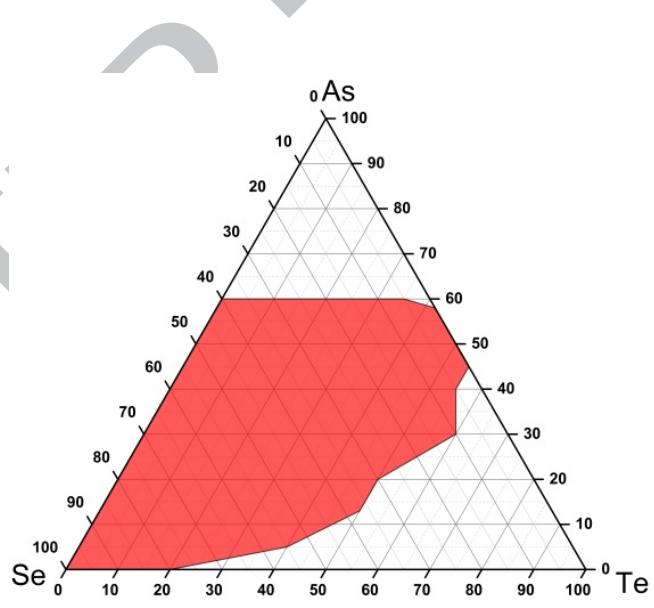

Fig. 2. TAS glasses forming domain. Reprinted with permission from Ref. [27].

Shiryaev et al.[29] prepared a series of samples with different Se and Te ratios and systematically studied the effect of $\mathrm{Te}_{x} \mathrm{As}_{40} \mathrm{Se}_{60-x}(x=0-40$, in mol\%) compositions on glass forming ability. The differential scanning calorimetry (DSC) of $\mathrm{Te}_{x} \mathrm{As}_{40} \mathrm{Se}_{60-x}$ samples at different heating rates were investigated. Fig. 3(a) shows the DSC results with the heating rate of $2.5 \mathrm{~K} / \mathrm{min}$. When $x=0,25,30,35,40$, there was an obvious 
crystallization peak; when $x=5,10,15$, there was a weak crystallization phenomenon; when $x=20$, there was no crystallization. When the heating rate was $5 \mathrm{~K} / \mathrm{min}$, as shown in Table 1, no crystallization occurred in the compositions of $x=10,15$, and 20. When the heating rate was $10 \mathrm{~K} / \mathrm{min}$, the $x=5,10,15$, and 20 compositions did not undergo crystallizations as shown in Fig. 3(b). From the formula $K_{\mathrm{gl}}=\left(T_{\mathrm{c}}-T_{\mathrm{g}}\right) /\left(T_{1}-T_{\mathrm{c}}\right)$ proposed by Hruby[30], we know that the interval $T_{\mathrm{c}}-T_{\mathrm{g}}$ is directly proportional to the glass-forming tendency and the $T_{1}-T_{\mathrm{c}}$ is indirectly proportional to the glass-forming tendency. Therefore, the TAS glasses of $x=5,10$, and 15 compositions were relatively stable. At different heating rates $(2.5,5$ and $10 \mathrm{~K} / \mathrm{min})$, only $\mathrm{Te}_{20} \mathrm{As}_{40} \mathrm{Se}_{40}$ had no crystallization peak, indicating that this glass was most stable.
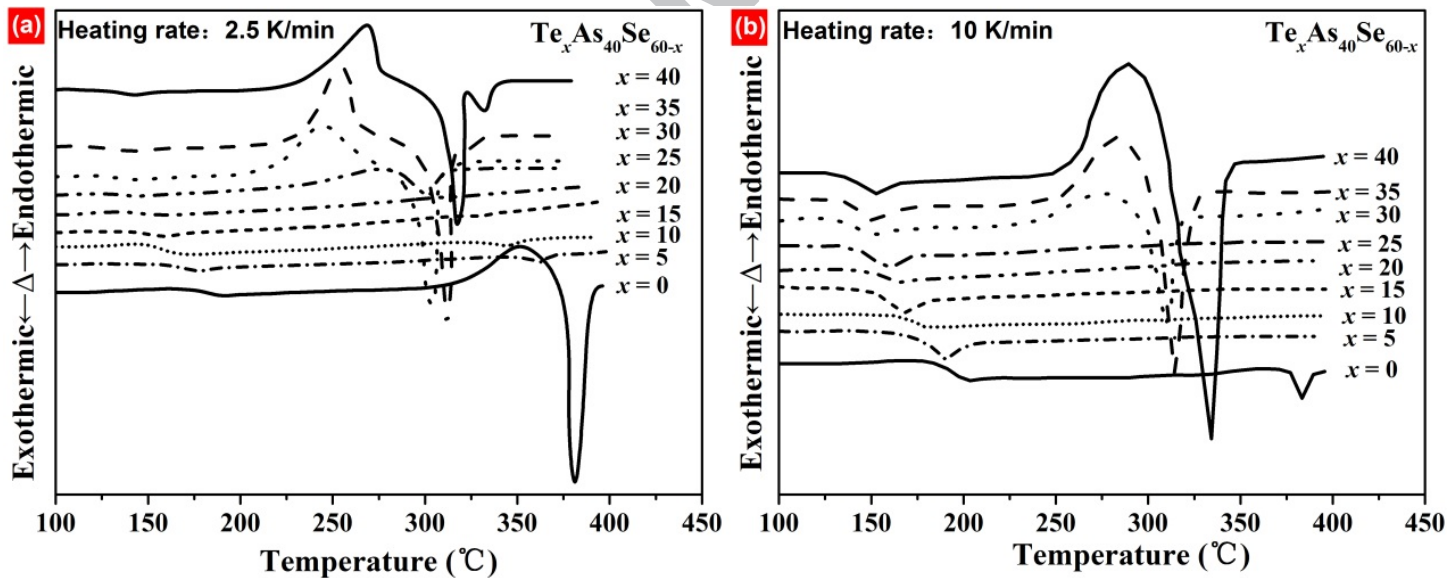

Fig. 3. DSC results for $\mathrm{Te}_{x} \mathrm{As}_{40} \mathrm{Se}_{60-x}$ glasses with heating rate of (a) $2.5 \mathrm{~K} / \mathrm{min}$, reprinted with permission from Ref. [29] and (b) $10 \mathrm{~K} / \mathrm{min}$. Reprinted with permission from Ref. [31]. 
Table 1. Temperature points and criteria of glass stability at heating rate of $5 \mathrm{~K} / \mathrm{min}$ for $\mathrm{As}_{40} \mathrm{Se}_{60-x} \mathrm{Te}_{x}$ glasses. Reprinted with permission from Ref. [31].

\begin{tabular}{ccccccccc}
\hline compositions & $T_{\mathrm{g}} /{ }^{\circ} \mathrm{C}$ & $T_{\mathrm{c}} /{ }^{\circ} \mathrm{C}$ & $T_{\mathrm{p}} /{ }^{\circ} \mathrm{C}$ & $T_{\mathrm{s}} /{ }^{\circ} \mathrm{C}$ & $T_{1} /{ }^{\circ} \mathrm{C}$ & $\Delta T /{ }^{\circ} \mathrm{C}$ & $K_{\mathrm{gl}}$ & $S / \mathrm{K}$ \\
\hline $\mathrm{As}_{40} \mathrm{Se}_{60}$ & 178 & 322 & 356 & 376 & 387 & 145 & 2.23 & 10.9 \\
$\mathrm{Te}_{5} \mathrm{As}_{40} \mathrm{Se}_{55}$ & 166 & 306 & 339 & 355 & 368 & 110 & 2.26 & 10.5 \\
$\mathrm{Te}_{10} \mathrm{As}_{40} \mathrm{Se}_{50}$ & 158 & - & - & - & - & - & - & - \\
$\mathrm{Te}_{15} \mathrm{As}_{40} \mathrm{Se}_{45}$ & 147 & - & - & - & - & - & - & - \\
$\mathrm{Te}_{20} \mathrm{As}_{40} \mathrm{Se}_{40}$ & 144 & - & - & - & - & - & - & - \\
$\mathrm{Te}_{25} \mathrm{Ass}_{40} \mathrm{Se}_{35}$ & 140 & 290 & 309 & 330 & 348 & 150 & 2.58 & 6.9 \\
$\mathrm{Te}_{30} \mathrm{Ass}_{40} \mathrm{Se}_{30}$ & 130 & 245 & 271 & 297 & 313 & 115 & 1.69 & 7.4 \\
$\mathrm{Te}_{35} \mathrm{As}_{40} \mathrm{Se}_{25}$ & 131 & 244 & 271 & 304 & 327 & 113 & 1.36 & 7.4 \\
$\mathrm{Te}_{40} \mathrm{As}_{40} \mathrm{Se}_{20}$ & 132 & 246 & 277 & 309 & 336 & 114 & 1.28 & 8.5 \\
\hline
\end{tabular}

$T_{\mathrm{g}}$ : glass transition temperature, $T_{\mathrm{c}}$ : onset of crystallization temperature, $T_{\mathrm{p}}$ : peak of crystallization temperature, $T_{\mathrm{s}}$ : solidus temperature, $T_{1}$ : liquidus temperature, $\Delta T=T_{\mathrm{c}}-$ $T_{\mathrm{g}}, K_{\mathrm{gl}}=\left(T_{\mathrm{c}}-T_{\mathrm{g}}\right) /\left(T_{1}-T_{\mathrm{c}}\right) ; S=\left(T_{\mathrm{p}}-T_{\mathrm{c}}\right)\left(T_{\mathrm{c}}-T_{\mathrm{g}}\right) / T_{\mathrm{g}}$

As the DSC results shown, the $\mathrm{Te}_{20} \mathrm{As}_{40} \mathrm{Se}_{40}$ has good thermal stability which has been drawn to fiber. As shown in Fig. 4, the refractive indexes of $\mathrm{Te}_{20} \mathrm{As}_{40} \mathrm{Se}_{40}$ and $\mathrm{Te}_{18} \mathrm{As}_{40} \mathrm{Se}_{42}$ glasses can be close to 3, which was larger than that of silicate glasses. Table 2 shows the mechanical properties and optical windows of the $\mathrm{Te}_{20} \mathrm{As}_{40} \mathrm{Se}_{40}$, TeX and $\mathrm{Ge}_{25} \mathrm{Sb}_{10} \mathrm{~S}_{65}$ glasses. TeX glasses, which are built up with Te, Se, and halide elements, show a broad optical transmission in the mid infrared from 2 to about 20 $\mu \mathrm{m}$, but poor mechanical properties. In contrast, the mechanical behavior of $\mathrm{Ge}_{25} \mathrm{Sb}_{10} \mathrm{~S}_{65}$ is improved, but the transmission is limited to $12 \mu \mathrm{m}$ in the infrared. Between these glasses, TAS glass is an interesting compromise for many applications, with correct mechanical properties and broad-enough transmission range for detection in the molecular fingerprint region. 


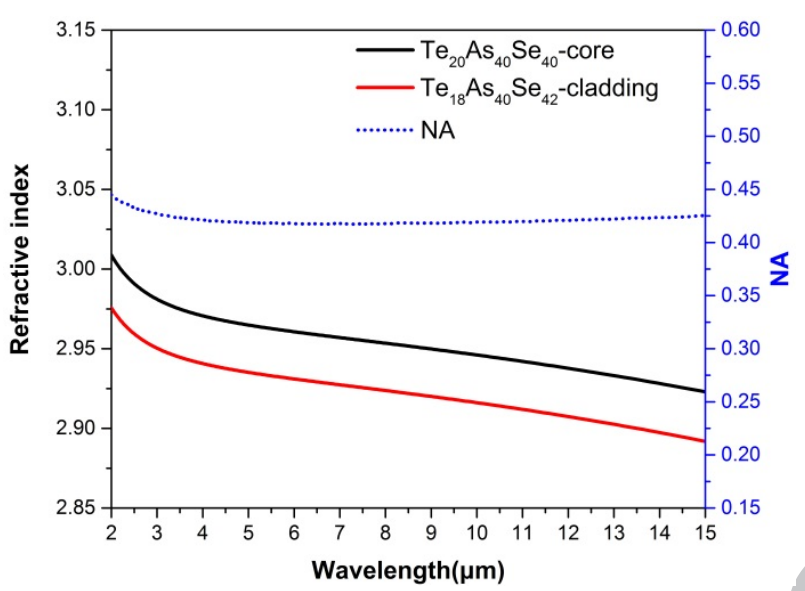

Fig. 4. Refractive indices of fiber core $\left(\mathrm{Te}_{20} \mathrm{As}_{40} \mathrm{Se}_{40}\right)$ and cladding $\left(\mathrm{Te}_{18} \mathrm{As}_{40} \mathrm{Se}_{42}\right)$ and the calculated NA. Reprinted with permission from Ref. [18].

Table 2. Young's modulus $E$, density $\rho$, linear coefficient of thermal expansion $\alpha$, micro hardeness $H_{\mathrm{v}}, T_{\mathrm{g}}$, and optical windows of the $\mathrm{Te}_{20} \mathrm{As}_{40} \mathrm{Se}_{40}, \mathrm{Ge}_{25} \mathrm{Sb}_{10} \mathrm{~S}_{65}$ and TeX glasses[32] [33].

\begin{tabular}{ccccccc}
\hline Glass & $E / \mathrm{GPa}$ & $\rho /\left(\mathrm{g} \cdot \mathrm{cm}^{-3}\right)$ & $\alpha / \mathrm{K}^{-1}$ & $H_{\mathrm{v}} /\left(\mathrm{kg} \cdot \mathrm{mm}^{-2}\right)$ & $T_{\mathrm{g}} /{ }^{\circ} \mathrm{C}$ & $\begin{array}{c}\text { Optical } \\
\text { windows } / \mu \mathrm{m}\end{array}$ \\
\hline $\mathrm{Te}_{20} \mathrm{As}_{40} \mathrm{Se}_{40}$ & 18.0 & 5.07 & $23 \times 10^{-6}$ & 146 & 144 & $2-16$ \\
\hline $\mathrm{Ge}_{25} \mathrm{Sb}_{10} \mathrm{~S}_{65}$ & 18.5 & 3.4 & $15.7 \times 10^{-6}$ & 155 & 320 & $2-11$ \\
\hline TeX glasses & 8 & & & & 60 & $2-20$ \\
\hline
\end{tabular}

\subsection{Structure of TAS glasses}

Delaizir et al. investigated the atomic structure of chalcogenide glasses $\mathrm{As}_{3} \mathrm{Se}_{7-x} \mathrm{Te}_{x}$ $(0 \leq x \leq 3)$ and $\mathrm{As}_{2} \mathrm{Se}_{3-x} \mathrm{Te}_{x}(0 \leq x \leq 2.5)$ by Wide-Angle X-ray Scattering (WAXS), ${ }^{77} \mathrm{Se}$ NMR as well as Raman and infrared measurements for different compositions[34]. It was shown that the progressive introduction of tellurium in $\mathrm{Te}_{x} \mathrm{As}_{3} \mathrm{Se}_{7-x}$ or $\mathrm{Te}_{x} \mathrm{As}_{2} \mathrm{Se}_{3-x}$ induced breaking of Se-Se bonds and the formation of $\mathrm{Te}_{x} \mathrm{AsSe}_{3-x}$ pyramidal units. Experimental data also revealed the absence of Te-Te bonds even in the tellurium richest composition which let suppose a homogeneous repartition of tellurium atoms in the glassy network. 
Jóvári et al. researched the structure of $\mathrm{Te}_{20} \mathrm{As}_{30} \mathrm{Se}_{50}$ glass by X-ray and neutron diffraction as well as extended X-ray absorption fine structure measurements at the As-, Se-, and Te $K$-edges[35]. The five datasets were modelled simultaneously by the reverse Monte Carlo simulation technique. Fig. 5 shows all the chemical bonds in $\mathrm{Te}_{20} \mathrm{As}_{30} \mathrm{Se}_{50}$ glass network, which was a pyramid network structure. Experimental data could be fitted satisfactorily by allowing As-Se, As-Te and Se-Te bonds only. All atoms satisfy the $8-N$ rule $\left(N_{\mathrm{As}}=3, N_{\mathrm{Se}}=N_{\mathrm{Te}}=2\right)$ and the affinity of As was much higher to Se than to Te. Chalcogen atoms preferentially bonded to As atom, and Se-Te bonds were formed only after saturating all valences of As.

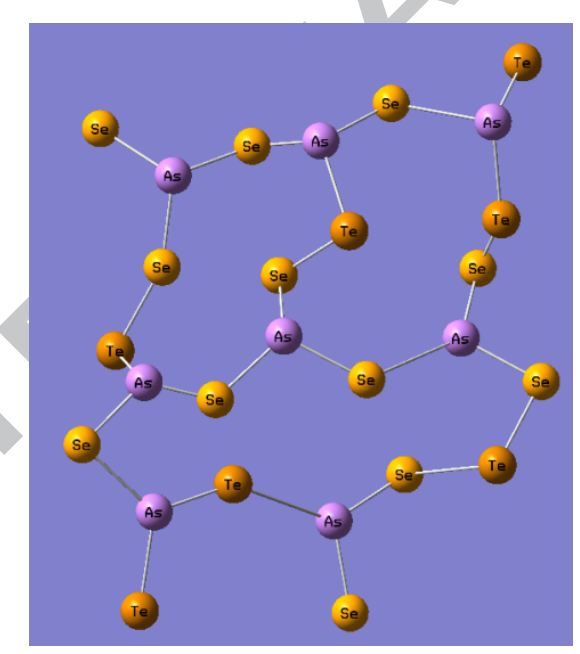

Fig. 5. The atomic structures of $\mathrm{Te}_{20} \mathrm{As}_{30} \mathrm{Se}_{50}$. Reprinted with permission from Ref. [35].

\section{Impurity and purification of TAS glasses}

The infrared transmission properties of ChG glasses are sensitive to impurities. The impurities in TAS glasses can be divided into two types. The first one is the impurity combined with the glass network or dissolved in the glass matrix. Such impurities usually absorb light selectively. In the fiber loss spectrum, the corresponding 
absorption peak size is determined by the corresponding impurity concentration, such impurities are mainly combined with $\mathrm{H}$ and $\mathrm{O}$. The second one is different from the refractive index of glass, which exhibits scattering of light and then increases the loss of the entire infrared bands including holes, microcrystalline particles and solid inclusions such as $\mathrm{SiO}_{2}$, carbon, transition metal oxides, etc.

There are three types of impurity sources for TAS glasses [32]. The first category is mainly from raw materials: commercial materials (Te, As, Se) have a purity of $5 \mathrm{~N}$ (99.999\%), thus impurities such as oxygen, molecular water, carbon, and transition metals in the raw materials should be removed as much as possible. Table 3 lists the melting point and purification methods of the raw materials.

Table 3. Melting points, boiling points and purification methods of TAS glasses raw materials.

\begin{tabular}{cccc}
\hline elements & melting point $/{ }^{\circ} \mathrm{C}$ & boiling points $/{ }^{\circ} \mathrm{C}$ & purification methods \\
\hline $\mathrm{Te}$ & 450 & 988 & $\begin{array}{c}\text { zone melting, distillation invacuum } \\
\text { or chemical etching } \\
\text { sublimation in Ar stream or } \\
\text { As }\end{array}$ \\
vacuum
\end{tabular}

The second source is from the container for the synthesis of glass at a high temperature. Silica glass tubes are the main container material used for the synthesis of ChG glasses. Hydrogen and silicon dioxide impurities are introduced from the walls of the silica glass tubes. The impurities with high diffusion coefficients, especially hydrogen, can enter the TAS melts easily. It was found that hydrogen started to enter the TAS melts from the silica glass tubes, containing $100 \mathrm{ppm}$ of hydrogen, beginning from $650{ }^{\circ} \mathrm{C}$. The temperature $T$ dependence of a hydrogen 
entrance rate $v\left(\mathrm{~g} \cdot \mathrm{cm}^{-2} \cdot \mathrm{s}^{-1}\right)$ is described by the expression: $\ln v=-11.2-(15300 / T)$, the range of $T$ is $873 \sim 1023 \mathrm{~K}$ [32]. The chemical interaction of $\mathrm{ChG}$ and impurities with silica glass tubes at high temperatures results in the formation of a thin layer on its surface. Owing to the difference in thermo-mechanical properties of the glass matrix and the layers, these layers can be separated from the silica glass tubes and enter the TAS melts to form heterogeneous inclusions, which were represented by $\alpha$ cristobalite impured with $\beta$-cristobalite[32].

The third type of impurity source mainly comes from the reaction of residual gas in the air with TAS glass during vacuuming. Impurities embedded in the glass network include $\mathrm{O}-\mathrm{H}$, Se- $\mathrm{H}, \mathrm{H}_{2} \mathrm{O}$, As- $\mathrm{H}$ as well as $\mathrm{N}_{2}, \mathrm{CO}_{2}$ and the like. The common impurities in TAS glasses and their corresponding absorption peak wavelengths were described in Ref. [32]. Generally $\mathrm{O}-\mathrm{H}, \mathrm{H}_{2} \mathrm{O}$, Se-H, and S-H bonds are relatively difficult to remove.

In addition, for the impurities commonly found in the above TAS glasses, impurity mass fraction can be calculated easily according to the Lambert-Beer law, $I=I_{0} \exp (-$ $\varepsilon x L$ ), where $I$ and $I_{0}$ are the light fluxes of sample output and input, respectively, $\varepsilon$ is the extinction coefficient, $x$ is the impurity mass fraction, and $L$ is the distance (here is the sample thickness). Table 4 shows the extinction coefficients that can be found for some known impurities. 
Table 4. Extinction coefficients of impurities in TAS glasses. Reprinted with permission from Ref. [32].

\begin{tabular}{cc}
\hline Impurities & Extinction coefficient $(\mathrm{dB} / \mathrm{m})$ \\
\hline $\mathrm{Se}-\mathrm{H}$ & $1 \times 10^{-3}$ \\
$\mathrm{As}_{2} \mathrm{O}_{3}$ & $1.03 \times 10^{-3}$ \\
$\mathrm{Se}-\mathrm{O}$ & $3.8 \times 10^{-4}$ \\
$\mathrm{CO}_{2}$ & $1.5 \times 10^{-2}$ \\
\hline
\end{tabular}

For preparing TAS glasses with better performance, the key problem to be solved is to design the purification process to remove the impurities as much as possible. Common oxygen getters such as $\mathrm{Al}$ (or $\mathrm{Mg}$ ) and hydrogen getters such as $\mathrm{TeCl}_{4}$ (or $\mathrm{GaCl}_{3}, \mathrm{AlCl}_{3}$ ) were usually mixed and used together into the raw materials for distillation and purification to synthesize glasses. Table 5 shows the mass fraction of impurities measured by different methods[29]. The addition of $\mathrm{AlCl}_{3}$ can effectively remove hydrogen impurity (about 10 times reduction), and also reduce oxygen and silicon. The carbon mass fraction was almost unchanged, and the mass fraction of metal element impurities was determined by the raw materials and the purification process. Adding an appropriate amount of $\mathrm{Al}$ as oxygen getter can effectively reduce the oxygen absorption peak; however this way had a large disadvantage, which would significantly enhance the content of the Se-H peak. It was estimated that the mass fraction of hydrogen could from 0.5 to $4 \mathrm{ppm}$, when $\mathrm{Al}$ exceeds $1 \mathrm{ppm}$, the molecular $\mathrm{H}_{2} \mathrm{O}$ in the glasses network was effectively decomposed. Subsequently the decomposed oxygen and Al formed highly volatile substances, which were removed by distillation, resulting in forming $\mathrm{Se}-\mathrm{H}$ peak by remaining hydrogen and $\mathrm{Se}$ elements. 
Table 5. Impurity content (ppm wt.) in TAS glasses prepared by different methods.

Reprinted with permission from Ref. [29].

\begin{tabular}{cccc}
\hline Impurities & Direct synthesis & Melting with Al & Melting with $\mathrm{AlCl}_{3}$ \\
\hline $\mathrm{C}$ & 1 & 0.6 & 1 \\
$\mathrm{O}$ & 20 & 0.2 & 0.6 \\
$\mathrm{H}$ & 0.2 & 1 & 0.02 \\
$\mathrm{Si}$ & 6 & 4 & 0.5 \\
$\mathrm{Al}$ & $<0.4$ & $<0.5$ & 0.1 \\
$\mathrm{Cu}$ & $<0.1$ & $<0.1$ & $<0.02$ \\
$\mathrm{Fe}$ & 1 & 0.8 & $<0.05$ \\
$\mathrm{Cr}, \mathrm{Ni}$ & $<2$ & $<2$ & $<0.03$ \\
$\mathrm{Mg}$ & 0.5 & $<0.3$ & $<0.01$ \\
$\mathrm{Sn}, \mathrm{Cd}$ & $<0.4$ & $<0.5$ & $<0.3$ \\
$\mathrm{Mn}$ & 0.1 & $<0.1$ & $<0.03$ \\
$\mathrm{Zn}$ & $<0.3$ & $<0.3$ & $<0.2$ \\
$\mathrm{~Pb}$ & $<0.5$ & $<0.7$ & $<0.03$ \\
\hline
\end{tabular}

To further improve the purity, Hocdé and Shiryaev et al. ameliorated the glass preparation technology and obtained high-purity optical fiber preforms. Hocdé et al. designed the experimental apparatus as illustrated in Fig. 6[36]. Firstly, the As and Se of $5 \mathrm{~N}$ purity were heated and evaporated at $290{ }^{\circ} \mathrm{C}$ and $250{ }^{\circ} \mathrm{C}$ respectively during the vacuuming process to remove the oxide impurities and molecular water. Subsequently As and Te were introduced into the double chambers tube together with Se. After sealed, the double chambers tube was heated with a temperature gradient furnace designed for melting the elements in the hot zone and then for purification of the melt by distillation into the cold zone. After resealed, the high purity glass was homogenized in a rocking furnace at $700{ }^{\circ} \mathrm{C}$ and then cooled down close to the $T_{g}$ $\left(127^{\circ} \mathrm{C}\right)$. At this temperature, the glass was annealed for several hours and slowly cooled to room temperature. Finally, the high purity TAS glasses were obtained. 


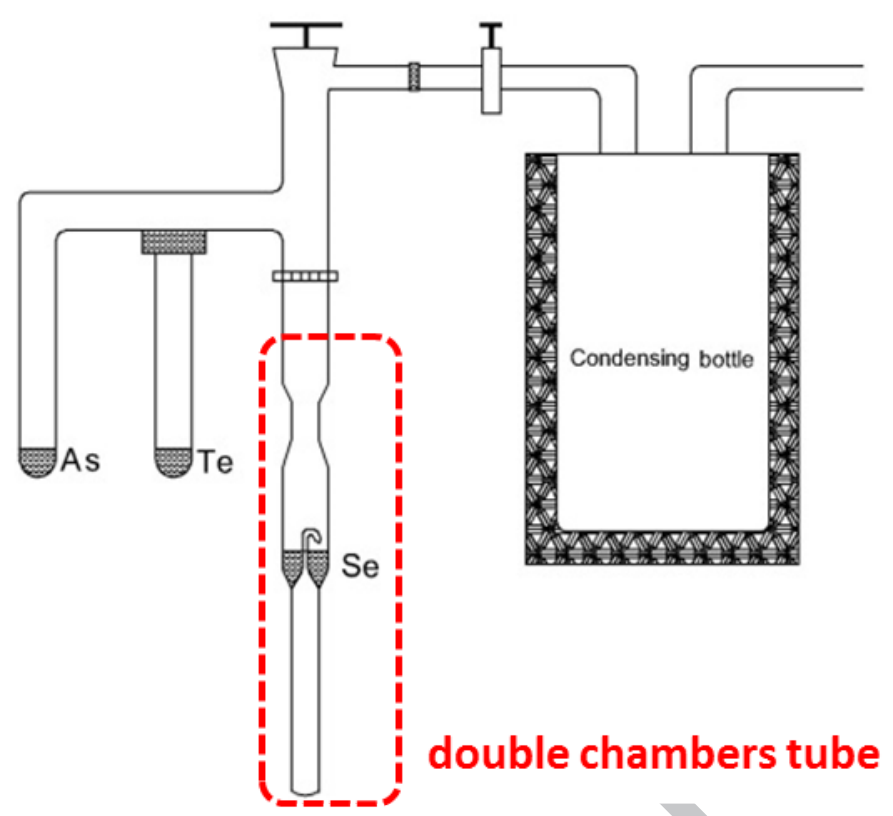

Fig. 6. Experimental set-up used for the purification of the starting elements, Te, As,

Se. Reprinted with permission from Ref. [36].

Shiryaev et al. studied the distillation purification technology of TAS glasses using the apparatus shown in Fig. 7[20]. First, before using the apparatus, the raw materials As, Se and Te with $5 \mathrm{~N}$ purity were separately distilled with a low evaporation rate to remove impurities such as oxygen, molecular water, carbon, silicon dioxide and heavy metals. Then 0.07 wt. $\%$ of $\mathrm{Al}$ as an oxygen scavenger was added in the high-purity raw material after distillation, uniformly mixed and vacuumed. $\mathrm{Al}_{2} \mathrm{O}_{3}$ was formed in this process to reduce the oxygen-containing components in raw materials. After sealed, the silica tube was placed in a rocking furnace at $850^{\circ} \mathrm{C}$ for $12 \mathrm{~h}$ and cooled to $400{ }^{\circ} \mathrm{C}$. Then, it was not necessary to perform quenching and annealing, and the silica tube for melting was directly connected to the double distillation apparatus shown in Fig. 7. The silica tube 1 was filled with Al-containing Te-As-Se glass melt, the silica tube 2 was used as an intermediate transition device, and the silica tube 3 was used for 
storing the glass melt obtained by the final distillation. The device 5 was silica glass filter, device 6 was a magnetic hammer-breaker used to remove metal impurities which may exist in the vaporized glass melt. The silica tube 1 was first heated to distill the glass melt to the silica tube 2. The boiling point of $\mathrm{Al}_{2} \mathrm{O}_{3}$ is as high as 2980 ${ }^{\circ} \mathrm{C}$, causing it to remain in silica tube 1 during the subsequent distillation process. Then, the heating temperature of the silica tube 1 was maintained, and the silica tube 2 was heated to condense the glass melt in the silica tube 3. After the second distillation, the silica tube 3 was sealed, melted and homogenized at $700{ }^{\circ} \mathrm{C}$ for $7 \mathrm{~h}$. Finally, high purity TAS glasses were obtained by quenching and annealing.

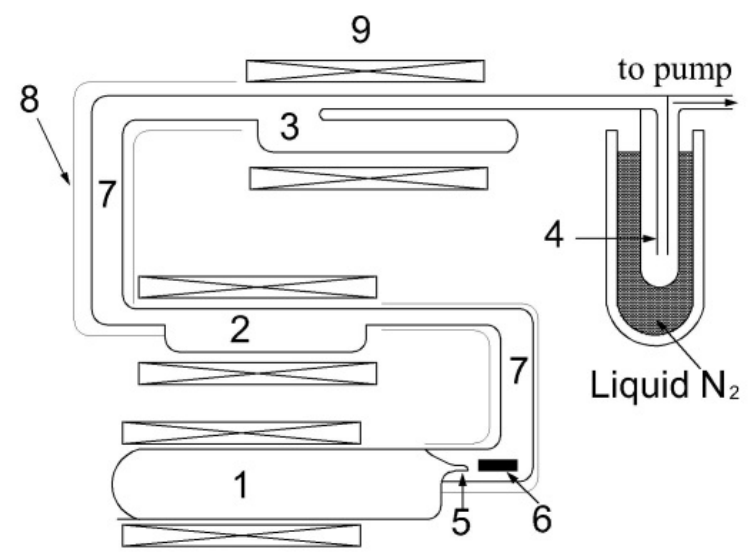

Fig. 7. Set-up for preparing high purity Te-As-Se glasses: 1-silica glass tube with TeAs-Se glass melt after interact with Al getter; 2-intermediate ampoule; 3-synthesis reactor; 4-trap for light volatile impurities; 5-glass partition; 6-magnetic hammerbreaker; 7- silica glass tube; 8-wireheater; 9-furnace. Reprinted with permission from Ref. [20].

\section{TAS glasses transmission and fiber loss}

The short cut-off wavelength of $\mathrm{ChG}$ glasses are caused by electronic transitions, 
while the IR edge depends mainly on the lattice vibration of the material. The transmission spectrum of the purified glass is shown in Fig. 8(a), especially at 2-12 $\mu \mathrm{m}$ has excellent transmittance[36]. Shiryaev et al. added $700 \mathrm{ppm}$ Al to purify the glass preform and drawed the TAS fibers, the lowest losses of the unclad $\mathrm{Te}_{25} \mathrm{As}_{40} \mathrm{Se}_{35}$ and $\mathrm{Te}_{20} \mathrm{As}_{30} \mathrm{Se}_{50}$ fibers were $0.07 \mathrm{~dB} / \mathrm{m} @ 7.3 \mu \mathrm{m}$ and $0.04 \mathrm{~dB} / \mathrm{m} @ 6.7 \mu \mathrm{m}$, respectively[20]. In 2006, their group prepared the single mode step-index $\left(\mathrm{Te}_{18.6} \mathrm{As}_{39} \mathrm{Se}_{42.4} / \mathrm{Te}_{18.3} \mathrm{As}_{39} \mathrm{Se}_{42.7}\right)$ glass fiber, the minimum loss was about $0.33 \mathrm{~dB} / \mathrm{m}$ at $7.5 \mu \mathrm{m}[37]$. As shown in Fig. 8(b), the large loss peak in the range of $4-5 \mu \mathrm{m}$ was mainly due to the influence of Se-H bond, and the loss peak at $6.3 \mu \mathrm{m}$ was affected by $\mathrm{H}_{2} \mathrm{O}$. Lv et al. reduced the C-O peak of the drawn TAS fiber from $1.4 \mathrm{~dB} / \mathrm{m}$ to 1.1 $\mathrm{dB} / \mathrm{m}$ by simultaneously improving the TAS glass purification and melting process[38]; the Se-H peak dropped from $1.4 \mathrm{~dB} / \mathrm{m}$ to $0.9 \mathrm{~dB} / \mathrm{m}$; As-O peak decreased from $9.8 \mathrm{~dB} / \mathrm{m}$ to $6 \mathrm{~dB} / \mathrm{m}$.
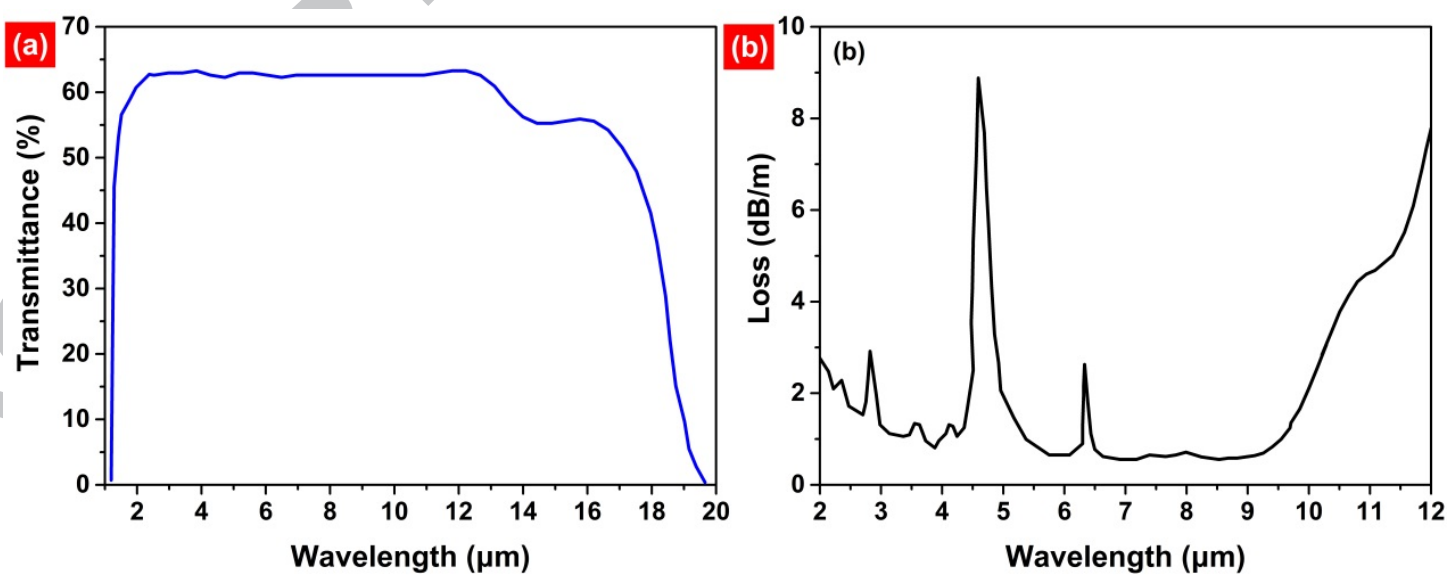

Fig. 8. (a) IR transmission spectrum of the $\mathrm{Te}_{20} \mathrm{As}_{30} \mathrm{Se}_{50}$ glass, reprinted with permission from Ref. [27]; (b)Loss of the $\mathrm{Te}_{20} \mathrm{As}_{30} \mathrm{Se}_{50}$ fiber. Reprinted with permission from Ref. [39].

Recently, our group have new progress in TAS fibers. Fig. 9(a) shows the MIR 
transmission spectra of $\mathrm{Te}_{20} \mathrm{As}_{40} \mathrm{Se}_{40}$ glass before and after purification. The impurity peaks of the purified glass like $\mathrm{O}-\mathrm{H}$, As-O, Se-O, Si-O and $\mathrm{H}_{2} \mathrm{O}$ were removed substantially, but the Se-H peak was increased. As shown in Fig. 9(b), the loss remarkably diminished compared after purification, and the unclad $\mathrm{Te}_{20} \mathrm{As}_{40} \mathrm{Se}_{40}$ glass fiber with minimum loss of $1.7 \mathrm{~dB} / \mathrm{m} @ 8.8 \mu \mathrm{m}$ was obtained.
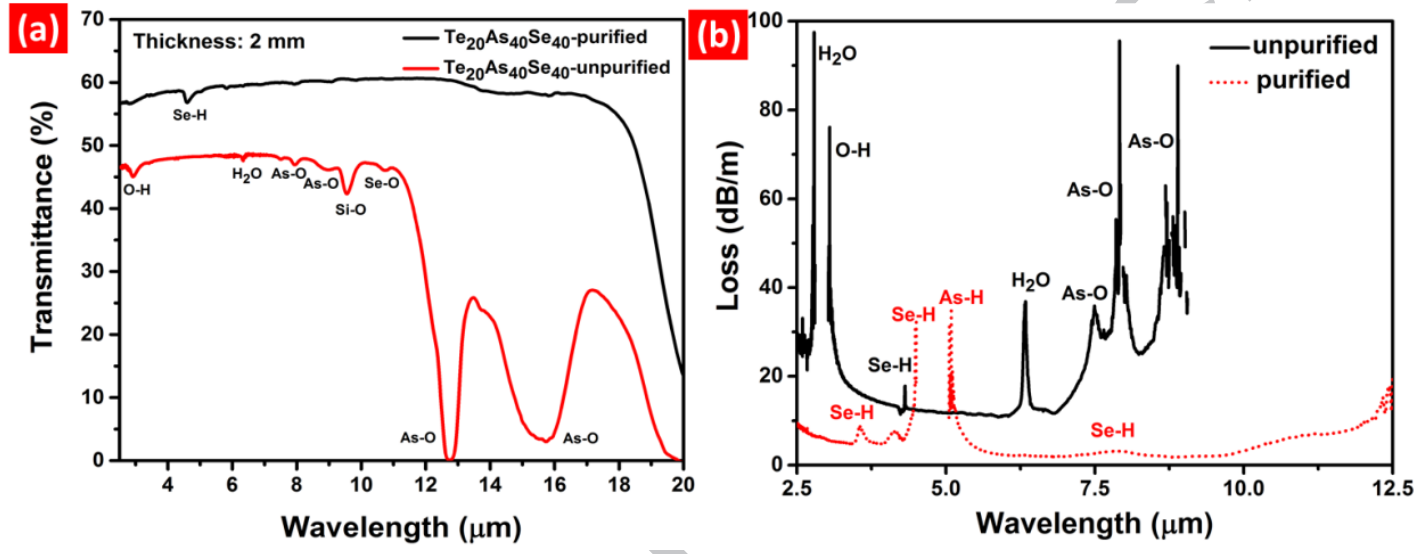

Fig. 9. (a) MIR transmission spectra of $\mathrm{Te}_{20} \mathrm{As}_{40} \mathrm{Se}_{40}$ glass before and after

purification and (b) Losses of unclad fibers prepared by using purified and unpurified $\mathrm{Te}_{20} \mathrm{As}_{40} \mathrm{Se}_{40}$ glass. Reprinted with permission from Ref. [18].

Désévédavy et al. drew TAS glass into microstructured fiber for the first time[40]. Its cross-sectional view was shown in Fig. 10(a). Single mode transmission could be achieved with a loss of $9 \mathrm{~dB} / \mathrm{m} @ 3.39 \mu \mathrm{m}$ and $6 \mathrm{~dB} / \mathrm{m} @ 9 \mu \mathrm{m}$, respectively. The predicted loss is expected to be reduced to $1 \mathrm{~dB} / \mathrm{m}$. The fiber loss would be up to 20 $30 \mathrm{~dB} / \mathrm{m}$ when the interstitials holes were collapsed[41]. Fig. 10(b) shows the fundamental mode transmission of $3.39 \mu \mathrm{m}$ and Gaussian fitting, and the software simulation was basically consistent with the experimental results. 

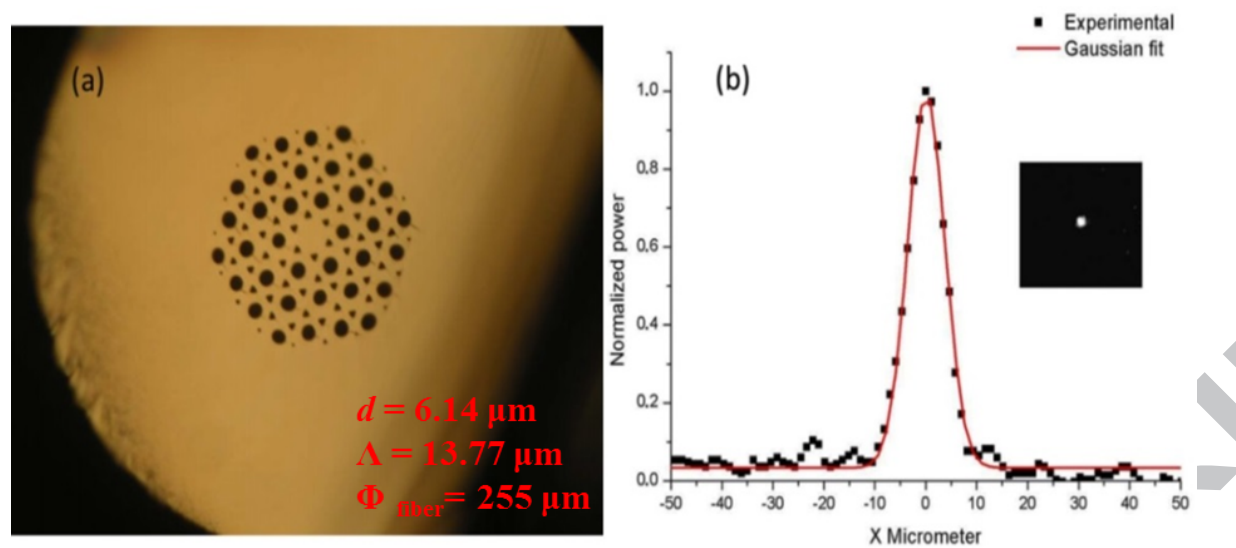

Fig. 10. (a) Microscope image of TAS microstructured fiber, the hole diameter $d$ is

$6.14 \mu \mathrm{m}$ and the pitch $\Lambda$ is $13.77 \mu \mathrm{m}$ (distance between two adjacent hole centers), the outer diameter is $255 \mu \mathrm{m}$; (b) Experimental profile of the output beam at $3.39 \mu \mathrm{m}$ in microstructured TAS fiber together with its Gaussian fit and the inset is a near-field observation of the guided mode at $3.39 \mu \mathrm{m}$. Reprinted with permission from Ref. $[40]$.

\section{The applications of TAS glasses}

\subsection{Fiber sensing}

The types of fiber sensor mainly include reaction cell light absorption type sensing, sensitive film light reflection and scattering type sensing, fluorescence type sensing, phosphorescence type sensing and evanescent field response type sensing [42]. Currently, TAS fiber sensor is mainly based on the principle of fiber evanescent wave spectroscopy (FEWS), that is, evanescent field response type sensing. Because of the spectral range cover the domain where are located the main IR signatures of molecules and biomolecules, TAS FEWS has been carried out to get some fruitful information in biology and medicine for early stage diagnosis or food safety[43].

According to Snell's law, when the incident angle of light is bigger than the critical 
angle $\theta_{\mathrm{c}}$, then total internal reflection (TIR) occurs at the interface between the fiber (unclad ) and air. The result of interaction with the reflected light is the generation of standing wave near the interface. In general, the phase of the light changes as it is reflected, the amplitude of the standing wave at the interface will be limited. The detailed explanation of Maxwell's equation shows that the standing wave is exponentially attenuated when it extends along the reflection cross section to a medium with a low refractive index, which called evanescent wave. A key parameter is the penetration depth $\left(d_{\mathrm{p}}\right)$ of the evanescent field for sensing detection [44].

$$
d_{\mathrm{p}}=\frac{\lambda}{2 \pi \sqrt{n_{1}{ }^{2} \sin ^{2} \theta-n_{2}{ }^{2}}}
$$

where $\lambda$ is the light wavelength, $n_{2}$ and $n_{1}$ are the refractive indices of the fiber and surrounding detection substance, respectively; $\theta$ is the angle of incidence of the wave in the fiber. The penetration of the evanescent wave increases linearly with the wavelength. When the optical fiber is in contact with the liquid to be tested, the infrared light is absorbed by the corresponding characteristic frequency chemical bond to exhibit a characteristic absorption spectrum. According to the absorption spectrum obtained by the contact of the evanescent wave on the surface of the fiber with the substance to be tested, it is extremely possible to detect the chemical substance and concentration, which does not destroy the substance itself and realizes remote sensing[45]. To improve the sensitivity of the FEWS detection and make the evanescent wave be more diffused into the sample, usually, the structure of the optical fiber is modfied. For example, the core-cladding and the tapered fibers as well as the single/multimode fibers combination, fiber bonding and other methods[43]. The 
FEWS principle of normal fiber and tapered fiber set-up is shown in Fig. 11, respectively. The sensing zone in contact with the sample to be tested generally utilizes the tapered fiber, because the number of total internal reflections in the taper region is significantly increased, resulting that the sensitivity of the sensing can be effectively enhanced [46].

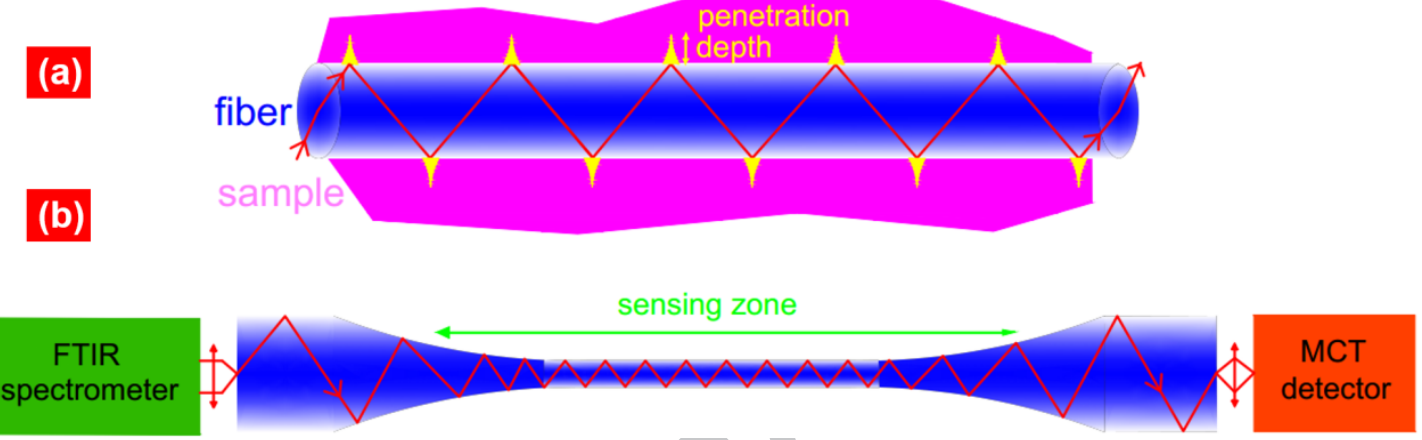

Fig. 11. Principle of FEWS: (a) Normal fiber, (b) Tapered fiber.

TAS fibers have excellent MIR transmission characteristics as well as corrosion resistance and insensitivity to electromagnetic wave. Therefore, researchers have extensive research in the fields of biological and liquid sensing.

TAS fibers in biology detection: Keirsse et al. built a TAS fibers sensing set-up composed by a TAS tapered fiber, a Fourier transformed infrared (FTIR) spectrometer and a liquid nitrogen-cooled $\mathrm{HgCdTe}$ (MCT) detector. They applied FEWS principle for different condition (hunger and normal) to study mice' liver cells and detected the diseased tissue cells successfully. Bureau et al. constructed a experimental set-up as shown in Fig. 12. TAS tapered fibers were both used as transmission and sensing elements. As shown in Fig. 13, the symmetry and asymmetry vibrations of $\mathrm{CH}_{2}$ groups were successfully detected at $2853 \mathrm{~cm}^{-1}$ and $2926 \mathrm{~cm}^{-1}$, respectively. Besides, the symmetrical and asymmetric vibrations of the 
$\mathrm{CH}_{3}$ group were successfully detected at $2871 \mathrm{~cm}^{-1}$ and $2960 \mathrm{~cm}^{-1}$, respectively. Lucas et al. used TAS tapered fiber to place human lung cells with Triton X-100, and successfully detected infrared spectral changes caused by methyl and methylene hydrocarbons in the range of $2800-3000 \mathrm{~cm}^{-1}$, which demonstrated the possibility of the ChG fibers for cell-based biosensors[47]. TAS fiber biosensors, small, simple and sensitive, can monitor various metabolic cells in situ, which can used for early diagnosis of tumors and cancers in medical fields. Therefore, it has extremely inclusive prospects in medicine and microbiology applications[19].

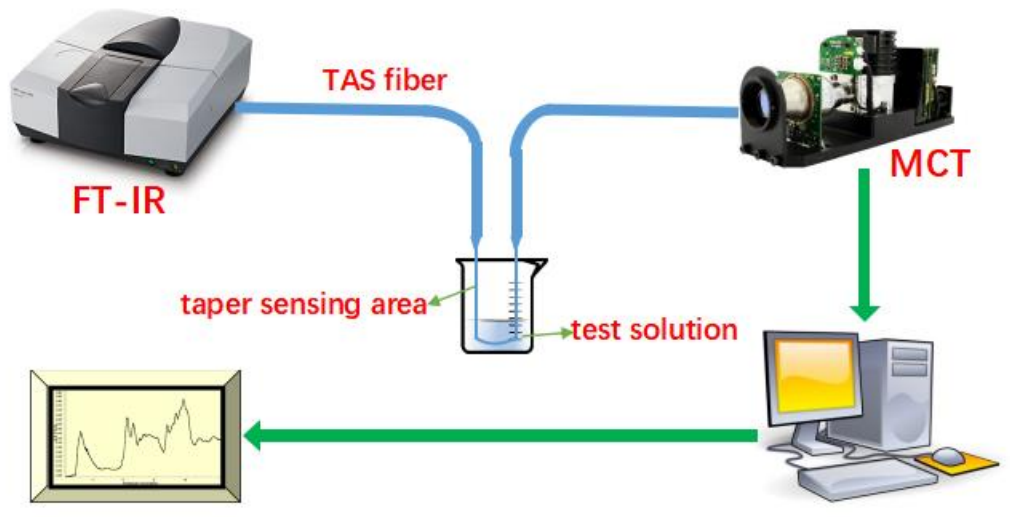

Fig. 12. The monitoring experiment of human lung cell. Reprinted with permission from Ref. [48]. 


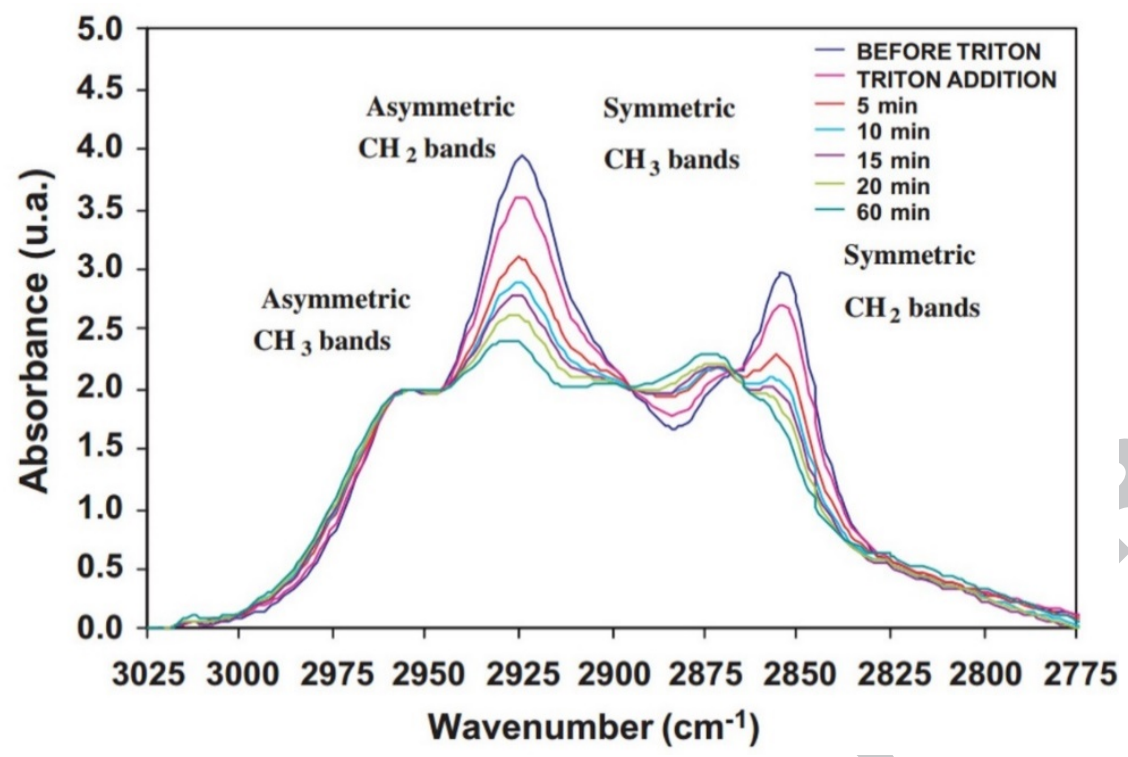

Fig. 13. Infrared spectra of human lung cell recorded with the TAS glass fiber.

Reprinted with permission from Ref. [48].

TAS fibers in liquid detection: Hocdé et al. used a TAS tapered fiber in a dichloromethane liquid and successfully detected the spectra of acetone $(\mathrm{C}=\mathrm{O})$ with different concentration and tracked the $\mathrm{C}=\mathrm{O}$ absorption spectra as time changed, which is shown in Fig. 14. Michel et al. used a $0.2 \mathrm{~m}$ long TAS tapered fiber in an artificial water storage system to measure the presence of $\mathrm{C}_{2} \mathrm{Cl}_{4}$ organic contaminants, finding that the spectrum changed mainly at $908 \mathrm{~cm}^{-1}$ shown in Fig. 15. The longer detection time and the higer concentration of the tested liquid, resulting in the more obvious spectral absorption peak; the lowest concentration of the detected pollutant was $1 \mathrm{mg} / \mathrm{dm}^{3}(1 \mathrm{ppm})$. Besides, they used the TAS tapered fiber protected by special metal and plastic to measure the volatile organic compounds like $\mathrm{C}_{2} \mathrm{Cl}_{4}, \mathrm{C}_{2} \mathrm{HCl}_{3}$, $\mathrm{C}_{6} \mathrm{H}_{4} \mathrm{Cl}_{2}$, which was in the groundwater of the dustrial lands in Paris and Technical University of Munich. The characteristic peak absorption was detected at the corresponding $1036 \mathrm{~cm}^{-1}, 1255 \mathrm{~cm}^{-1}$, and $910 \mathrm{~cm}^{-1}$ in the IR spectra, respectively, as 
shown in Fig. 16. TAS fibers can be applied for tracking control and liquid sensing monitoring in chemical reaction processes, effectively improves human's living environment and food quality.
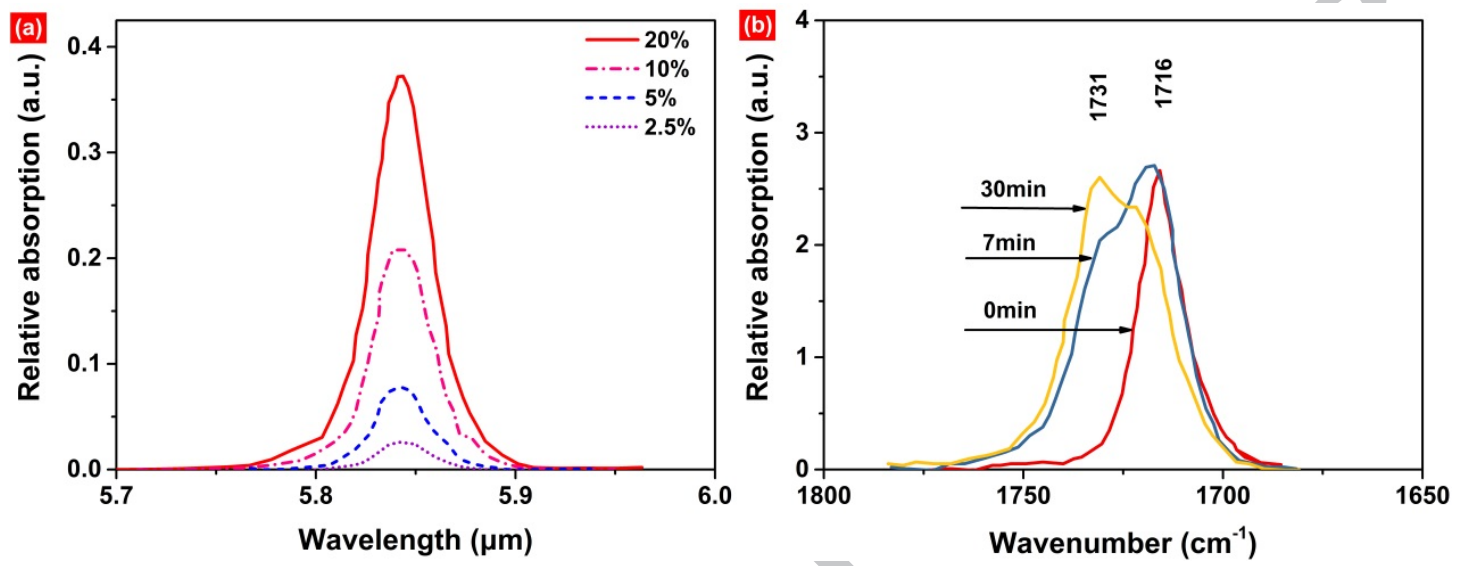

Fig. 14. (a)Detection of $\mathrm{C}=\mathrm{O}$ band of acetone at different volumic percentages in methylene chloride using FEWS; (b) $\mathrm{C}=\mathrm{O}$ band shift at different times during microwave assisted organic reaction. The reaction kinetics is followed in situ by FEWS. Reprinted with permission from Ref. [49].

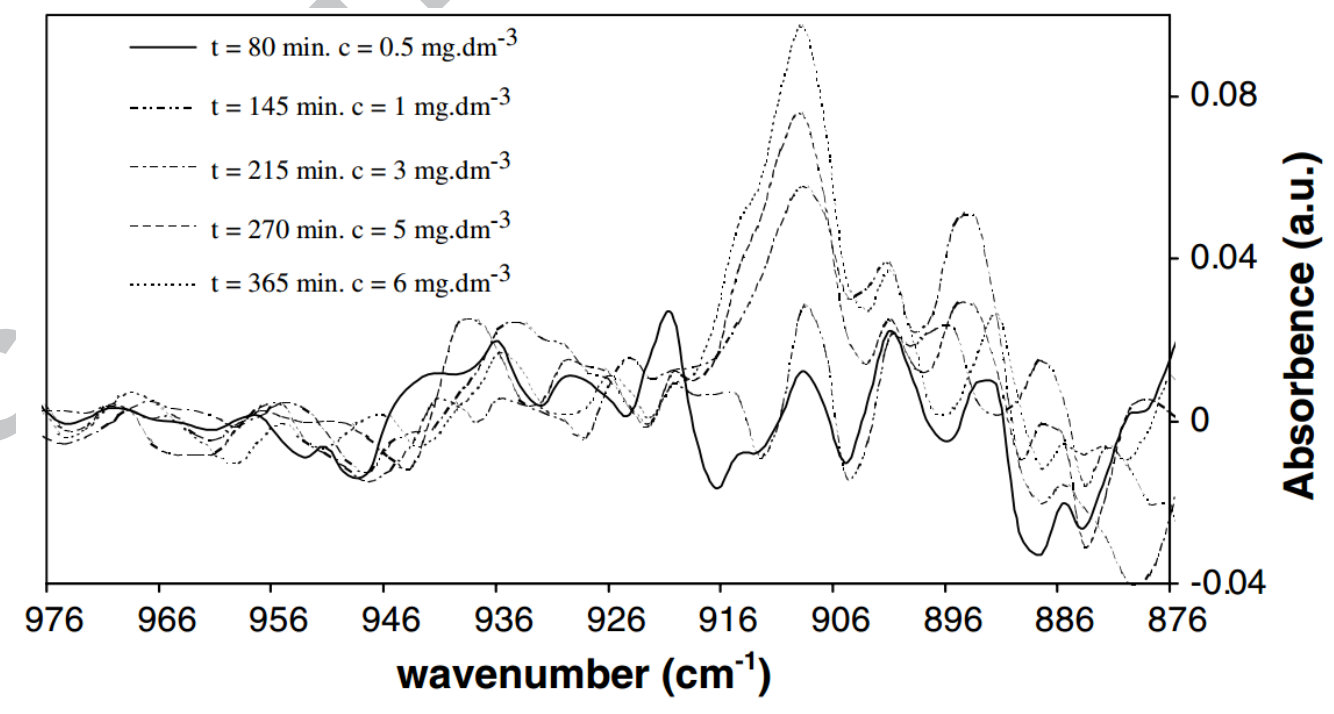

Fig. 15. Evolution of the absorbence of the $\mathrm{C}_{2} \mathrm{Cl}_{4}$ line at $908 \mathrm{~cm}^{-1}$ for a length of immersion of the fiber equal to $0.2 \mathrm{~m}$. Reprinted with permission from Ref. [50]. 

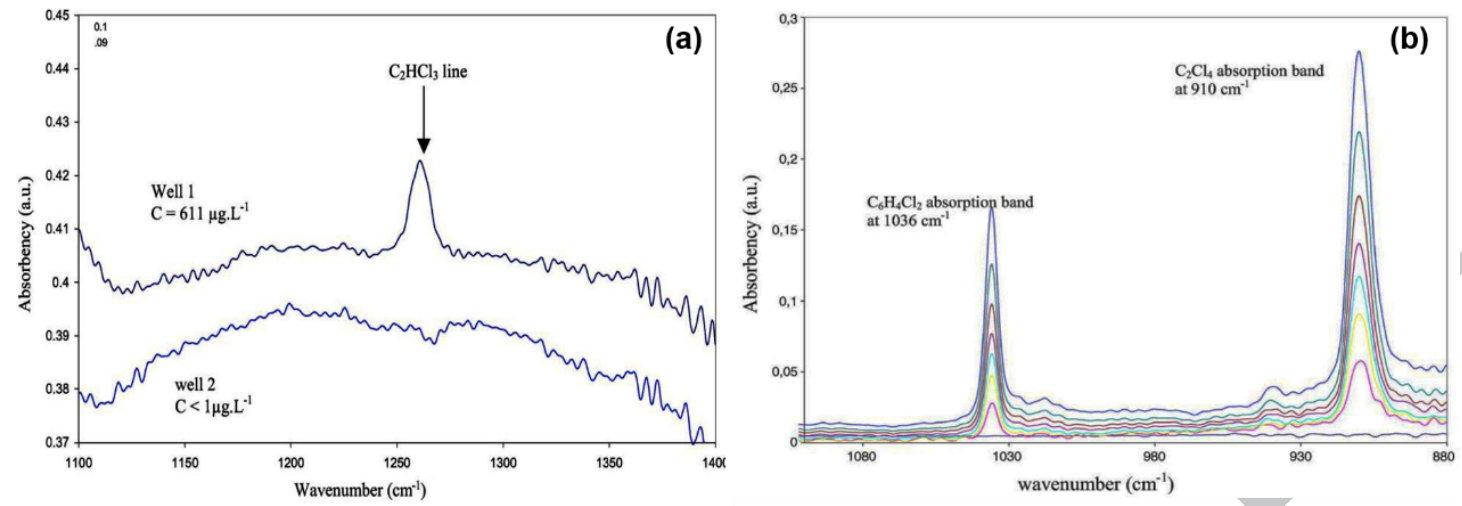

Fig. 16. (a) Spectra recorded near Paris in an industrial fallow land mainly polluted by trichloroethylene $\left(\mathrm{C}_{2} \mathrm{HCl}_{3}\right)$. The absorption band of $\mathrm{C}_{2} \mathrm{HCl}_{3}$ at $1255 \mathrm{~cm}^{-1}$ was clearly evidenced for the well 1 and not detectable for the well 2 in agreement with the chemical analysis results; (b) Spectra recorded in Munich in a natural aquifer. It encompassed the both bands of $\mathrm{C}_{2} \mathrm{Cl}_{4}$ at $910 \mathrm{~cm}^{-1}$ and of $\mathrm{C}_{6} \mathrm{H}_{4} \mathrm{Cl}_{2}$ at $1036 \mathrm{~cm}^{-1}$ showing that several pollutants can be detected simultaneously. Reprinted with permission from Ref. [39].

The research team in University of Rennes 1 committed to the research of fiber sensing for early disease diagnosis. In June 2011, DIAFIR was founded by an interdisciplinary team of researchers and engineers. Their product, fiber evanescent wave sensor, can be made great use of medical diagnosis shown in Fig. 17. TAS tapered fiber was used to collect information from serum. The system, equipped with an intuitive touch screen interface and a spectrum processing algorithm to directly diagnose the score, only requires a small detection source with $1 \mathrm{~mm}^{2}$ of tissue or 10 $\mu 1$ of liquid sample (1 drop) [51]. Thanks to timeliness and high sensitivity, it saves hospital stays through invasive and time-consuming surgery and helps doctors get more accurate results and better care for patients. Until now, the non-invasive test has 
been developed to diagnose the non-alcoholic steato-hepatitis (or NASH) and acute septic arthritis[52, 53].

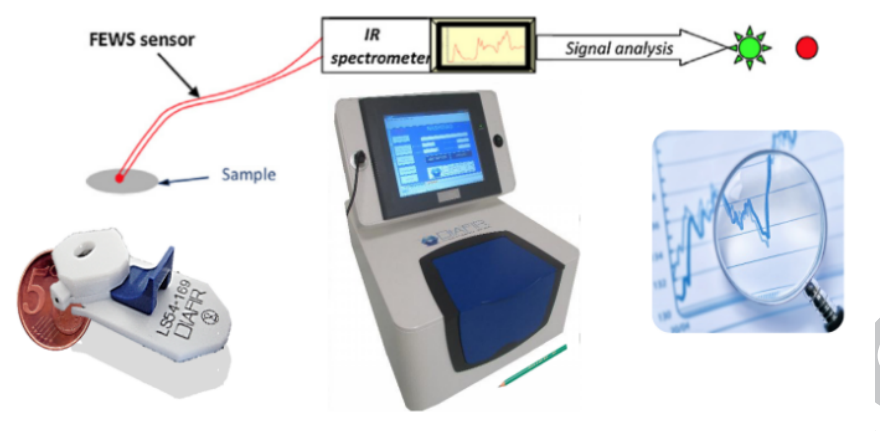

Fig. 17. DIAFIR company's product in France: TAS fiber evanescent wave sensor

\subsection{Laser delivery \& light propagation}

Kosolapav et al prepared a TAS microstructured hollow-core fiber shown in Fig. 18, which was firstly demonstrated that it was possible to use the TAS microstructured hollow-core fiber for propagating the $10.6 \mu \mathrm{m} \mathrm{CO}_{2}$-laser radiation. A further improvement of the technology and design of such fibers is expected to yield a reduction of the optical loss to below $1 \mathrm{~dB} / \mathrm{m}$. This TAS microstructured hollow-core fiber has great promise for the delivery of the $\mathrm{CO}_{2}$-laser radiation since the light is well limited at the fiber center.

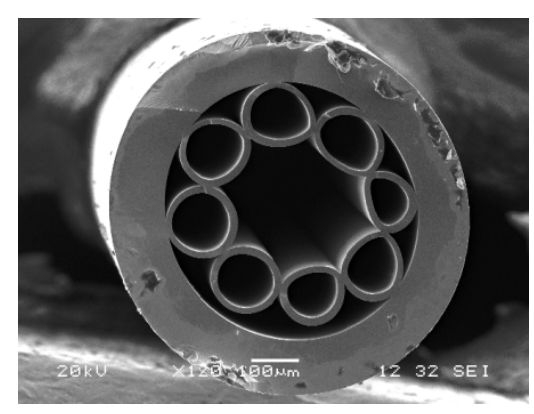

Fig. 18. Fiber cross-section photograph obtained by SEM. Reprinted with permission from Ref. [54].

Houizot et al. successfully used the single mode TAS fibers as the wavefront 
filters to join the DARWIN mission[55], which could successfully detect the the weak infrared emission lines of like $\mathrm{O}_{3}$ and $\mathrm{H}_{2} \mathrm{O}$ on earth-like planets, the scheme as shown in Fig. 19.

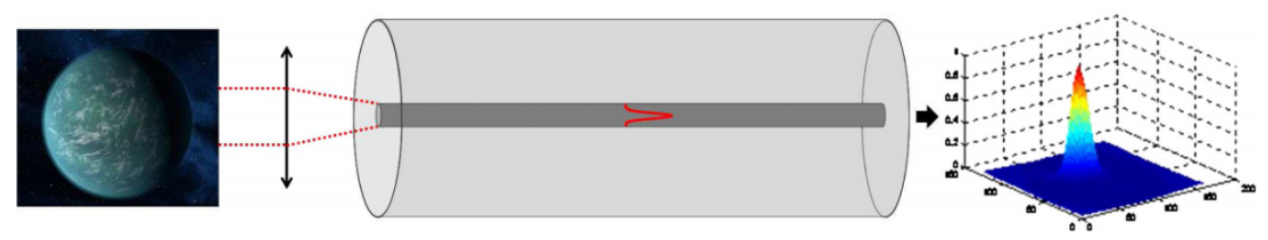

Fig. 19. Optical scheme of the detection of the MIR signal coming from an exo-planet through space. The beam profile on the right corresponds to a single-mode TAS glass at $10.6 \mu \mathrm{m}$. Reprinted with permission from Ref. [19].

\subsection{Supercontinuum generation}

The MIR SC generation spectra of ChG fibers, especially the ultra-broadband spectra covering 2-13 $\mu \mathrm{m}$ molecular fingerprint band, are expected to be developed new IR light sources $[56,57]$. TAS glasses have high nonlinear refractive index and wide MIR transmission [17], resulting that TAS glasses are more suitable for drawing fibers to obtain ultra-wide spectral conversion than binary sulfur arsenic compounds. Until now, there are few reports on the SC spectra of TAS fibers. Anashkina et al. proposed and optimized theoretically a SC laser source in the MIR using Te-AsSe/As-S step-index fiber and pumped by a center wavelength of 150 fs pulse femtosecond all-fiber laser system at $2 \mu \mathrm{m}[58]$. Numerically simulated spectra extending from $\sim 1 \mu \mathrm{m}$ to $>8 \mu \mathrm{m}$ were demonstrated with pumping energy of $100 \mathrm{pJ}$. Recently, our group have been reported the broadest SC generation spectrum (1.8-13 $\mu \mathrm{m}$ with a $30 \mathrm{~dB}$ spectral flatness) by pumping the unclad $\mathrm{Te}_{20} \mathrm{As}_{40} \mathrm{Se}_{40}$ fiber in the normal dispersion region at $5 \mu \mathrm{m}$ femtosecond laser at different pump powers as 
shown in Fig. 20(a), which covers almost all the transparent range of the material. By pumping the $\mathrm{Te}_{20} \mathrm{As}_{40} \mathrm{Se}_{40} / \mathrm{Te}_{18} \mathrm{As}_{40} \mathrm{Se}_{42}$ step-index fiber in the normal dispersion region at $5 \mu \mathrm{m}$, the $\mathrm{SC}$ spectrum covering $2.1-11.2 \mu \mathrm{m}$ with a $40 \mathrm{~dB}$ flatness was recorded(Fig. 20(b))[18].
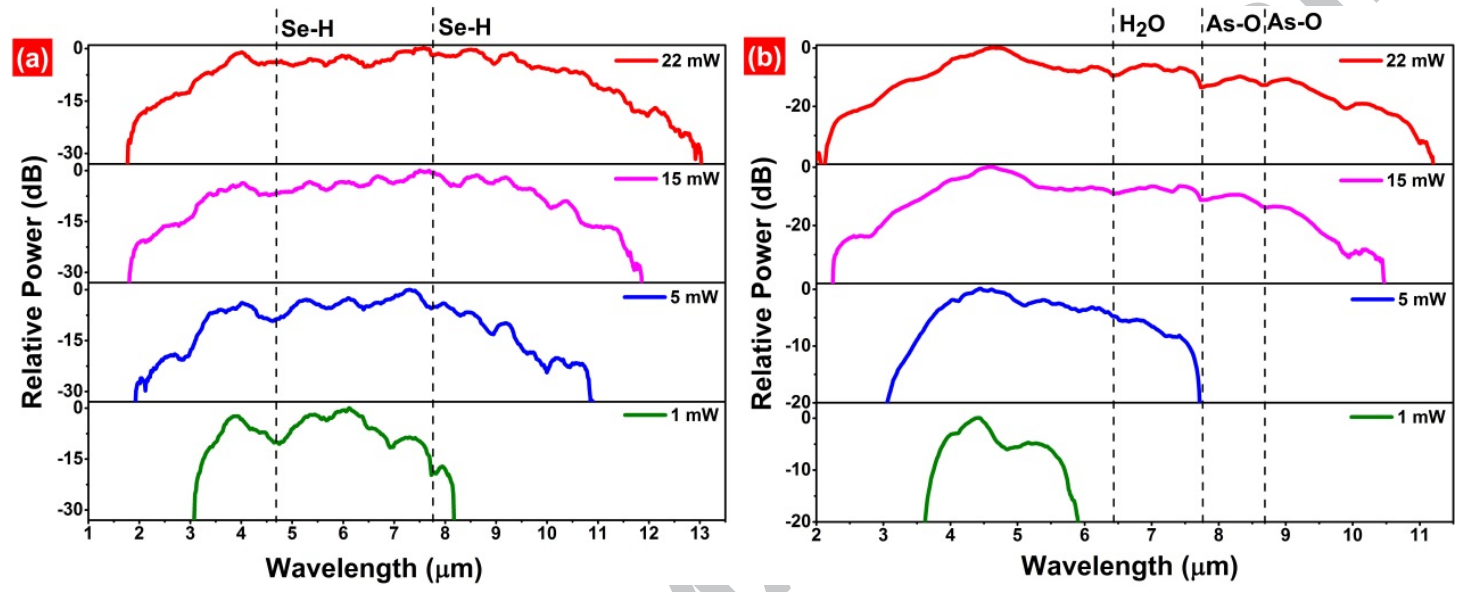

Fig. 20. Spectra of SC at different output power pumped for (a) an unclad

$\mathrm{Te}_{20} \mathrm{As}_{40} \mathrm{Se}_{40}$ fiber and (b) a $\mathrm{Te}_{20} \mathrm{As}_{40} \mathrm{Se}_{40} / \mathrm{Te}_{18} \mathrm{As}_{40} \mathrm{Se}_{42}$ step-index fiber. Reprinted with permission from Ref. [18].

\section{Conclusion and Prospect}

In conclusion, formation of Te-As-Se glasses, their thermal and optical properties, purification technology, the fiber preparation technology, as well as fiber sensing principle and the research progress in sensing applications were reviewed. Although the research of Te-As-Se glasses and fibers have been carried out for nearly half a century, there are still many problems to be solved: firstly, it is necessary to continuously improve the preparation and purification technology to reduce its loss, so as to improve light transmittance and the sensitivity in sensing research. Secondly, the commercial TAS fiber sensors have not appeared except DIAFIR company, therefore, it is necessary to increase its innovation and development with wide range 
of promotion and application. Finally, there is few TAS fibers report of SC spectrum pupmed by commercial laser, usually, large optical parametric amplifier (OPA) or optical parametric oscillator (OPO) is apply for pumping ChG fibers. Therefore, TAS fiber with proper waveguide dispersion should be designed, such as microstructure and tapered fibers, which makes zero dispersion wavelength blue shift and realize the broadband MIR SC generation.

\section{Acknowledgements}

This work was partially supported by the Zhejiang Provincial Natural Science Foundation of China (LY18F050004), Open Research Fund of State Key Laboratory of Transient Optics and Photonics (SKLST201705), National Natural Science Foundation of China (61627815), and K.C. Wong Magna Fund in Ningbo University. 


\section{References}

[1] G. Tao, H. Ebendorff-Heidepriem, A.M. Stolyarov, S. Danto, J.V. Badding, Y. Fink, J. Ballato, A.F. Abouraddy, Infrared fibers, Adv. Opt. Photon. 7 (2015) 379458.

[2] E.A. Anashkina, V.S. Shiryaev, M.Y. Koptev, B.S. Stepanov, S.V. Muravyev, Development of As-Se tapered suspended-core fibers for ultra-broadband mid-IR wavelength conversion, J. Non-Cryst. Solids 480 (2017) 43-50.

[3] J.-L. Adam, X. Zhang, Chalcogenide glasses, Woodhead Publishing, Cambridge, UK, 2014.

[4] L. Lan, H. Lin, S. Qiao, Z. Yi, S. Danto, K. Richardson, J.D. Musgraves, N. Lu, J. $\mathrm{Hu}$, Integrated flexible chalcogenide glass photonic devices, Nat. Photonics 8 (2014) 643-649.

[5] S. Sato, K. Igarashi, M. Taniwaki, K. Tanimoto, Y. Kikuchi, Multihundred-watt CO laser power delivery through chalcogenide glass fibers, Appl. Phys. Lett. 62 (1993) 669-671.

[6] A. Sincore, J. Cook, F. Tan, A. El Halawany, A. Riggins, S. McDaniel, G. Cook, D. Martyshkin, V. Fedorov, S. Mirov, High power single-mode delivery of midinfrared sources through chalcogenide fiber, Opt. Express 26 (2018) 7313-7323.

[7] H. Suto, Chalcogenide fiber bundle for 3D spectroscopy, Infrared Phys. Technol. 38 (1997) 93-99.

[8] B. Zhang, C. Zhai, S. Qi, W. Guo, Z. Yang, A. Yang, X. Gai, Y. Yu, R. Wang, D. Tang, G. Tao, B. Luther-Davies, High-resolution chalcogenide fiber bundles for 
infrared imaging, Opt. Lett. 40 (2015) 4384-4387.

[9] S. Qi, B. Zhang, C. Zhai, Y. Li, A. Yang, Y. Yu, D. Tang, Z. Yang, B. LutherDavies, High-resolution chalcogenide fiber bundles for longwave infrared imaging, Opt. Express 25 (2017) 26160-26165.

[10] C.R. Petersen, U. Møller, I. Kubat, B. Zhou, S. Dupont, J. Ramsay, T. Benson, S. Sujecki, N. Abdel-Moneim, Z. Tang, D. Furniss, A. Seddon, O. Bang, Mid-infrared supercontinuum covering the $1.4-13.3 \mu \mathrm{m}$ molecular fingerprint region using ultrahigh NA chalcogenide step-index fibre, Nat. Photonics 8 (2014) 830-834.

[11] Z. Zhao, B. Wu, X. Wang, Z. Pan, Z. Liu, P. Zhang, X. Shen, Q. Nie, S. Dai, R. Wang, Mid-infrared supercontinuum covering $2.0-16 \mu \mathrm{m}$ in a low-loss telluride single-mode fiber, Laser Photonics Rev. $11 \quad$ (2017) 1700005. http://dx.doi.org/10.1002/lpor.201700005

[12] N. Zhang, X. Peng, Y. Wang, S. Dai, Y. Yuan, J. Su, G. Li, P. Zhang, P. Yang, X. Wang, Ultrabroadband and coherent mid-infrared supercontinuum generation in Te-based chalcogenide tapered fiber with all-normal dispersion, Opt. Express 27 (2019) 10311-10319.

[13] R. Chahal, F. Starecki, C. Boussard-Plédel, J.L. Doualan, K. Michel, L. Brilland, A. Braud, P. Camy, B. Bureau, V. Nazabal, Fiber evanescent wave spectroscopy based on IR fluorescent chalcogenide fibers, Sens. Actuators B: Chem. 229 (2016) 209-216.

[14] A.K. Sharma, J. Gupta, R. Basu, Simulation and performance evaluation of fiber optic sensor for detection of hepatic malignancies in human liver tissues, Opt. Laser 
Technol. 98 (2018) 291-297.

[15] A.P. Velmuzhov, V.S. Shiryaev, M.V. Sukhanov, T.V. Kotereva, M.F. Churbanov, N.S. Zernova, A.D. Plekhovich, Fiber sensor on the basis of $\mathrm{Ge}_{26} \mathrm{As}_{17} \mathrm{Se}_{25} \mathrm{Te}_{32}$ glass for FEWS analysis, Opt. Mater. 75 (2018) 525-532.

[16] G. Yang, J.C. Sangleboeuf, C. Boussard-Plédel, B. Bureau, Effect of Physical Aging Conditions on the Mechanical Properties of $\mathrm{Te}_{2} \mathrm{As}_{3} \mathrm{Se}_{5}$ (TAS) Glass Fibers, J. Am. Ceram. Soc. 96 (2013) 464-468.

[17] D. Brandová, R. Svoboda, Thermo-structural characterization of $\left(\mathrm{As}_{2} \mathrm{Se}_{3}\right)_{100-\mathrm{x}}-\left(\mathrm{As}_{2} \mathrm{Te}_{3}\right)_{\mathrm{x}}$ glasses for infrared optics, J. Am. Ceram. Soc. 102 (2019) 382-396.

[18] Z. Wu, L. Yang, Y. Xu, P. Zhang, Q. Nie, X. Wang, 1.8-13 $\mu$ m supercontinuum generation by pumping at normal dispersion regime of As-Se-Te glass fiber, J. Am. Ceram. Soc. https://doi.org/10.1111/jace.16516.

[19] B. Bureau, C. Boussard, S. Cui, R. Chahal, M.-L. Anne, V. Nazabal, O. Sire, O. Loréal, P. Lucas, V. Monbet, Chalcogenide optical fibers for mid-infrared sensing, Opt. Eng. 53 (2014) 027101.

[20] V.S. Shiryaev, J.L. Adam, X.H. Zhang, C. Boussard-Plédel, J. Lucas, M.F. Churbanov, Infrared fibers based on Te-As-Se glass system with low optical losses, J. Non-Cryst. Solids 336 (2004) 113-119.

[21] S. Hocdé, O. Loréal, O. Sire, B. Turlin, C. Boussard-Plédel, D. Le Coq, B. Bureau, G. Fonteneau, C. Pigeon, P. Leroyer, J. Lucas, Biological tissue infrared analysis by chalcogenide glass optical fiber spectroscopy, in: Biomonitoring and 
Endoscopy Technologies, Porc. SPIE 4158, Amsterdam, Netherlands, 2001, pp. 4956.

[22] P. Lucas, G.J. Coleman, C. Cantoni, S. Jiang, T. Luo, B. Bureau, C. Boussardpledel, J. Troles, Z. Yang, Chalcogenide glass sensors for bio-molecule detection, in: Optical Fibers and Sensors for Medical Diagnostics and Treatment Applications XVII, Proc. SPIE 10058, San Francisco, California, US, 2017, pp. 100580Q. https://doi.org/10.1117/12.2257995

[23] M.F. Kotkata, S.R. Atalla, M.K. El-Mously, Measurement of the electrical and thermal conductivity coefficients of $\mathrm{As}_{2} \mathrm{Se}_{3}-\mathrm{As}_{2} \mathrm{Te}_{3}$ glassy alloys, in: G. Klemens, T. K. Chu (Eds.), Thermal Conductivity 14, Springer, US, 1976, pp. 39-44.

[24] Y. Sun, S. Dai, P. Zhang, X. Wang, Y. Xu, Z. Liu, F. Chen, Y. Wu, Y. Zhang, R. Wang, Fabrication and characterization of multimaterial chalcogenide glass fiber tapers with high numerical apertures, Opt. Express 23 (2015) 23472-23483.

[25] M.F. Chubanov, High-purity glasses based on arsenic chalcogenides, Optoelectron. Adv. Mater. 3 (2001) 341-349.

[26] T. Kanamori, Y. Terunuma, S. Takahashi, T. Miyashita, Chalcogenide glass fibers for mid-infrared transmission, J. Lightwave Technol. 2 (1984) 607-613.

[27] B. Bureau, C. Boussard-Pledel, P. Lucas, X. Zhang, J. Lucas, Forming glasses from Se and Te, Molecules 14 (2009) 4337-4350.

[28] Z.U. Borisova, Glassy Semiconductors, Springer US, 1981.

[29] V.S. Shiryaev, M.F. Churbanov, E.M. Dianov, V.G. Plotnichenko, J.L. Adam, J. Lucas, Recent progress in preparation of chalcogenide As-Se-Te glasses with low 
impurity content, J. Optoelectron. Adv. Mater. 7 (2005) 1773-1779.

[30] A. Hrubý, Evaluation of glass-forming tendency by means of DTA, Czechoslovak Journal of Physics B 22 (1972) 1187-1193.

[31] V.S. Shiryaev, J.L. Adam, X.H. Zhang, M.F. Churbanov, Study of characteristic temperatures and nonisothermal crystallization kinetics in As Se Te glass system, Solid State Sci. 7 (2005) 209-215.

[32] G. Snopatin, V. Shiryaev, V. Plotnichenko, E. Dianov, M. Churbanov, Highpurity chalcogenide glasses for fiber optics, Inorg. Mater. 45 (2009) 1439-1460.

[33] J. Lucas, X. Zhang, The tellurium halide glasses, J. Non-Cryst. Solids 125 (1990) $1-16$.

[34] G. Delaizir, M. Dussauze, V. Nazabal, P. Lecante, M. Dollé, P. Rozier, E.I. Kamitsos, P. Jovari, B. Bureau, Structural characterizations of As-Se-Te glasses, J. Alloys Compd. 509 (2011) 831-836.

[35] P. Jóvári, B. Bureau, I. Kaban, V. Nazabal, B. Beuneu, U. Rütt, The structure of $\mathrm{As}_{3} \mathrm{Se}_{5} \mathrm{Te}_{2}$ infrared optical glass, J. Alloys Compd. 488 (2009) 39-43.

[36] S. Hocdé, G. Fonteneau, J. Lucas, Chalcogens Based Glasses for IR Fiber Chemical Sensors, Solid State Sci. 3 (2001) 279-284.

[37] V. Shiryaev, C. Boussard-Plédel, P. Houizot, T. Jouan, J.-L. Adam, J. Lucas, Single-mode infrared fibers based on Te-As-Se glass system, Mater. Sci. Eng. B 127 (2006) 138-143.

[38] B. Lv, K. Yang, H. Lang, H. Xue, Effect of trace impurities on loss of As-Se-Te glass infrared fiber, Laser Infra. 31 (2001) 121-123. 
[39] K. Michel, B. Bureau, C. Boussard-Pledel, T. Jouan, J.L. Adam, K. Staubmann, T. Baumann, Monitoring of pollutant in waste water by infrared spectroscopy using chalcogenide glass optical fibers, Sens. Actuators B: Chem. 101 (2004) 252-259.

[40] F. Désévédavy, G. Renversez, J. Troles, L. Brilland, P. Houizot, Q. Coulombier, F. Smektala, N. Traynor, J.L. Adam, Te-As-Se glass microstructured optical fiber for the middle infrared, Appl. Opt. 48 (2009) 3860-3865.

[41] L. Brilland, J. Troles, P. Houizot, F. Desevedavy, Q. Coulombier, G. Renversez, T. Chartier, T.N. Nguyen, J.-L. Adam, N. Traynor, Interfaces impact on the transmission of chalcogenides photonic crystal fibres, J. Ceram. Soc. Jpn. 116 (2008) 1024-1027.

[42] M. Ramakrishnan, G. Rajan, Y. Semenova, G. Farrell, Overview of fiber optic sensor technologies for strain/temperature sensing applications in composite materials, Sensors $16(2016) 99$.

[43] B. Bureau, C. Boussard, V. Nazabal, J. Troles, Development of chalcogenide glass fibers for mid-IR technologies, in: Smart Photonic and Optoelectronic Integrated Circuits XX, Proc. SPIE 10536, San Francisco, California, United States, 2018, 1053605. https://doi.org/10.1117/12.2288557

[44] X. Jiang, A. Jha, Engineering of a Ge-Te-Se glass fibre evanescent wave spectroscopic (FEWS) mid-IR chemical sensor for the analysis of food and pharmaceutical products, Sens. Actuators B: Chem 206 (2015) 159-169.

[45] S. Cui, R. Chahal, C. Boussard-Plédel, V. Nazabal, J.L. Doualan, J. Troles, J. Lucas, B. Bureau, From selenium-to tellurium-based glass optical fibers for infrared 
spectroscopies, Molecules 18 (2013) 5373-5388.

[46] X. Jiang, A. Jha, An infrared fibre evanescent wave spectroscopic (FEWS) sensor using purified GeTeSe chalcogenide fibres, in: 20th International Conference on Optical Fibre Sensors, Proc. SPIE 7503, Edinburgh, United Kingdom, 2009, pp. 750319.

[47] P. Lucas, D. Le Coq, C. Juncker, J. Collier, D.E. Boesewetter, C. BoussardPlédel, B. Bureau, M.R. Riley, Evaluation of toxic agent effects on lung cells by fiber evanescent wave spectroscopy, Appl. Spectrosc. 59 (2005) 1-9.

[48] B. Bureau, X.H. Zhang, F. Smektala, J.L. Adam, J. Troles, H.L. Ma, C. Boussard-Plèdel, J. Lucas, P. Lucas, D. Le Coq, Recent advances in chalcogenide glasses, J. Non-Cryst. Solids 345-346 (2004) 276-283.

[49] S. Hocdé, C. Boussard-Plédel, G. Fonteneau, D. Le Coq, H.L. Ma, J. Lucas, Recent developments in chemical sensing using infrared glass fibers, J. Non-Cryst. Solids 274 (2000) 17-22.

[50] K. Michel, B. Bureau, C. Pouvreau, J.C. Sangleboeuf, C. Boussard-Plédel, T. Jouan, T. Rouxel, J.-L. Adam, K. Staubmann, H. Steinner, T. Baumann, A. Katzir, J. Bayona, W. Konz, Development of a chalcogenide glass fiber device for in situ pollutant detection, J. Non-Cryst. Solids 326-327 (2003) 434-438.

[51] M.L. Corvec, F. Charpentier, A. Kachenoura, S. Bensaid, S. Henno, E. BardouJacquet, B. Turlin, V. Monbet, L. Senhadji, O. Loréal, Fast and non-invasive medical diagnostic using mid infrared sensor: The AMNIFIR project, IRBM 37 (2016) 116123. 
[52] R. Anty, M. Le Corvec, A. Iannelli, S. Patouraux, M.-C. Saint-Paul, A.-S.

Schneck, C. Canivet, I. Ben-Amor, J. Gugenheim, O. Sire, Mid-infrared spectroscopy has a high sensitivity and specificity for point-of-care diagnosis of non-alcoholic steato-hepatitis, J. Hepato. 64 (2016) S177.

[53] J.-D. Albert, V. Monbet, A. Jolivet-Gougeon, N. Fatih, M. Le Corvec, M. Seck, F. Charpentier, G. Coiffier, C. Boussard-Plédel, B. Bureau, A novel method for a fast diagnosis of septic arthritis using mid infrared and deported spectroscopy, Joint Bone Spine 83 (2016) 318-323.

[54] A.F. Kosolapov, A.D. Pryamikov, M.S. Astapovich, V.S. Shiryaev, G.E. Snopatin, V.G. Plotnichenko, A.S. Biriukov, M.F. Churbanov, E.M. Dianov, Demonstration of waveguide regime for chalcogenide hollow-core optical fiber with negative curvature of core boundary from mid- to far-infrared, in: 2011 Conference on Lasers and Electro-Optics Europe and 12th European Quantum Electronics Conference (CLEO EUROPE/EQEC), IEEE, Munich, Germany, 2011.

[55] A.J. Faber, B. Bureau, C. Boussardplédel, J. Lucas, J.P.D. Carmo, L.K. Cheng, P. Houizot, P.A.V. Nijnatten, W.L.M. Gielesen, Infrared single mode chalcogenide glass fiber for space, Opt. Express 15 (2007) 12529-12538.

[56] P. Cimalla, J. Walther, M. Mittasch, E. Koch, Shear flow-induced optical inhomogeneity of blood assessed in vivo and in vitro by spectral domain optical coherence tomography in the $1.3 \mu \mathrm{m}$ wavelength range, J. Biomed. Opt. 16 (2011) 116020.

[57] C.R. Petersen, N. Prtljaga, M. Farries, J. Ward, B. Napier, G.R. Lloyd, J. Nallala, 
N. Stone, O. Bang, Mid-infrared multispectral tissue imaging using a chalcogenide fiber supercontinuum source, Opt. Lett. 43 (2018) 999-1002.

[58] E.A. Anashkina, V.S. Shiryaev, G.E. Snopatin, S.V. Muraviev, A.V. Kim, On the possibility of mid-IR supercontinuum generation in As-Se-Te/As-S core/clad fibers with all-fiber femtosecond pump source, J. Non-Cryst. Solids 480 (2017) 38-42.

Formation and properties of Te-As-Se glasses were reviewed.

$>$ Applications in optics and medical of Te-As-Se fibers were summarized.

$>$ Prospects of the applications in medical diagnosis and supercontinuum generation.

Declarations of interest: none 